\title{
MULTIPLE SCLEROSIS IN CHILDREN AND ADOLESCENTS
}

\section{MULTIPLA SKLEROZA KOD DECE I ADOLESCENATA}

\author{
Jasna Jančić, , Blažo Nikolić' , Šarlota Mesaroš̌2,5, Marija Mostarica Stojković3 , Tatjana Pekmezović, Jelena Drulović2,5
}

\section{Summary}

Multiple sclerosis in children and adolescents (PedMS) presents a significant challenge both in diagnostic and therapeutic terms. Developmental specificities are the cause of numerous differences in PedMS in relation to the adult form of multiple sclerosis (AoMS). In the field of basic and clinical neurological research, researchers' opinions are conflicted creating many questions and dilemmas, which suggest that PedMS is distinguished as a different and specific disease compared to AoMS.

Having in mind the ability of the developing brain to compensate for damage, leading to partial recovery, the imperative of adequate treatment is the early diagnosis and early administration of immunomodulatory therapy.

Key words: pediatric multiple sclerosis, epidemiology, immunopathogenic mechanisms, diagnosis, diagnostic criteria, magnetic resonance imaging, treatment, immunomodulatory therapy

\section{Sažetak}

Multipla skleroza u dečjoj i adolescentnoj populaciji (PedMS) predstavlja značajan izazov kako u dijagnostičkom, tako i u terapijskom smislu. Razvojne specifičnosti uslovljavaju brojne različitosti u odnosu na adultnu formu multiple skleroze (AoMS). Na polju neuroloških istraživanja, bazičnih i kliničkih, sukobljavaju se mišljenja naučnika otvarajući pitanja i dileme, upućujući na pretpostavku da ove posebnosti izdvajaju PedMS kao različitu bolest u odnosu na AoMS.

Poznavajući sposobnosti mozga da u razvoju kompenzuje oštećenja sa posledičnim delimičnim oporavkom, imperativ adekvatnog lečenja predstavlja rano postavljanje dijagnoze i što ranija primena imunomodulatorne terapije.

Ključne reči: pedijatrijska multipla skleroza, epidemiologija, imunopatogenetski mehanizmi, dijagnoza, dijagnostički kriterijumi, magnetna rezonanca, lečenje, imunomodulatorna terapija

\section{UvoD}

Pedijatrijska multipla skleroza (PedMS) je hronična, inflamatorna, i neurodegenerativna bolest centralnog nervnog sistema (CNS) (1). Multipla skleroza se najčešće javlja između 20. i 40. godine života, sa značajno manjom učestalošću u detinjstvu i kod starijih od 50 godina. Prvi patološki i klinički opis MS je dao profesor Žan Martin Šarko (Jean-Martin Charcot) u XIX veku, označavajući je kao sclerose en plaques (2). U narednim decenijama su usledile opsežne etiološke, patofiziološke i farmakološke studije, od otkrivanja genetičke osnove do primene imunomodulatorne/imunosupresivne terapije (3-5). Poslednjih godina, dijagnoza i lečenje pedijatrijskih pacijenata sa MS su privukli posebnu pažnju naučne zajednice (6). Kliničke karakteristike, laboratorijske analize i nalazi na magnetnoj rezonanci (MR), mogu se značajno razlikovati kod dece u odnosu na adultnu populaciju (7), dok individualni pristup ostaje presudan za rano dijagnostikovanje i terapiju pedijatrijskih pacijenata sa MS. Jednu od značajnih neuroloških kontroverzi poslednjih godina predstavlja i dilema da li je PedMS različita bolest u odnosu na adultnu multiplu sklerozu (AoMS) ili je samo kontinuum iste bolesti od dečjeg do adultnog doba $(8,9)$.
Etiologija PedMS i dalje nije u potpunosti poznata. PedMS je multifaktorijalna bolest na čiji nastanak utiču genetički i faktori životne sredine (10). Do sada je otkriveno više od 200 gena koji mogu da imaju ulogu u nastajanju MS $(11,12)$. Promene na humanom leukocitnom antigenu (HLA) DRB $1^{\star} 15$ alelu značajno povećavaju rizik i najverovatnije igraju najznačajniju ulogu u inicijaciji bolesti $(11,12)$. Pored genetičkih faktora, infekcija Epštajn - Barovim (Epstein-Barr) virusom (tzv. mehanizmom molekularne mimikrije), može biti povezana sa izmenjenim imunološkim odgovorom i predstavlja jedan od najznačajnijih etiopatogenetskih činilaca u MS $(13,14,17)$. Snižen nivo vitamina D i pušenje mogu da doprinesu nastanku MS (13-15). Pored ovih faktora, pominje se veza između gojaznosti i PedMS, kao posledica niskog nivoa vitamina $\mathrm{D}$, a s obzirom na pretežno deponovanje vitamina $\mathrm{D}$ u masnom tkivu. Ova korelacija nije još uvek u potpunosti razjašnjena (16). Nezavisno od nivoa vitamina $\mathrm{D}$, smanjenje gojaznosti može povećati rizik od PedMS. Nizak nivo serumskog vitamina D u ranim fazama trudnoće nosi sa sobom povećani rizik od PedMS kod potomstva (16). Izloženost citomegalovirusu (CMV) može da ima negativnu prediktivnu udruženost sa pojavom MS (17). 
Karakteristične patohistološke promene u PedMS su: konfluentna demijelinizacija sa znacima remijelinizacije, izraženija perivaskularna i parenhimska inflamacija ( $\mathrm{T}$ limocitima, B limocitima i plazma ćelijama), obilje makrofaga/mikroglije i akutno oštećenje aksona (18). Takođe se javlja demijelinizacija sive mase, korteksa i duboke sive mase, kao i remijelinizacija - posebno rane faze i korteks (18). Proizvodnja proinflamatornih citokina tokom izmenjenog imunološkog odgovora oštećuje oligodendrocite i mijelin, uzrokujući plakove zapaljenske demijelinizacije (19). Studije su pokazale da se kod dece sa MS javlja i do $50 \%$ veći stepen akutnog aksonskog oštećenja u odnosu na odrasle pacijente $(18,20)$.

Klinička slika bolesti kod dece je slična adultnoj, ali sa izvesnim specifičnostima: akutni multisistemski početak sa encefalopatijom i česta inicijalna prezentacija simptomima od strane malog mozga i moždanog stabla (9). U dečjoj populaciji su češće egzacerbacije bolesti, ali praćene boljim neurološkim oporavkom, uz sporiju progresiju bolesti i redak primarno progresivan tok (8, 9). I pored toga, deca dostižu ranije isti stepen onesposobljenosti u odnosu na pacijente kod kojih je bolest počela u odraslom dobu (8).

Epileptički napadi se češće javljaju kod bolesnika sa MS u odnosu na opštu populaciju, naročito u PedMS (21). Rezultati analiza faktora rizika za pojavu epilepsije ukazuju na povezanost kortikalnih/subkortikalnih lezija i epileptičkih napada. Kod PedMS se češće javljaju encefalopatski znaci, posebno kod dece mlađe od 10 godina $(21,22)$. Epileptični napadi se češće javljaju u sklopu multisimptomske prezentacije (glavobolja, groznica, povraćanje, letargija, epileptički napadi i psihičke izmene). Napadi predstavljaju početni simptom oboljenja kod 1/10 dece sa MS i epilepsijom (22). Etiopatogeneza epileptičnih napada kod PedMS nije u potpunosti rasvetljena. Pojedini autori smatraju da značajnu ulogu imaju veći broj i zapremina kortikalnih i subkortikalnih lezija (23). Napadi su najčešće fokalni i sekundarno generalizovani, a prognoza epilepsije kod PedMS je dobra $(21,22)$, sa povoljnim terapijskim odgovorom na antiepileptičke lekove.

Učestalost poremećaja u oblasti kognitivnog funkcionisanja je visoka, karakteriše ih brza deterioracija, ali i sposobnost delimičnog oporavka u dužem vremenskom periodu (24). Kognitivno narušenje se beleži u oko $30 \%$ pacijenata, pre svega u domenima egzekutivnih funkcija, brzini obrade informacija, vizuomotorne integracije i pažnje $(24,25)$. Pojedine studije navode da su jezički poremećaji (receptivni, fluentnost i imenovanje), kao i pad brzine procesiranja teži u PedMS (26). Takođe su zabeležena i loša akademska postignuća kod 26\% PedMS pacijenata, posebno u domenu matematike (27).Raniji početak bolesti i niži nivo intelektualnog funkcionisanja su prediktivni faktori u nastanku većeg kognitivnog oštećenja $(24,25)$. Iz tih razloga se ističe značaj rane kognitivne rehabilitacije i posebnih mera u povećanju kognitivne rezerve kod PedMS.

Na polju neuroloških istraživanja, bazičnih i kliničkih, sukobljavaju se mišljenja naučnika otvarajući pitanja i dileme, upućujući na pretpostavku da ove posebnosti možda izdvajaju PedMS kao različitu bolest u odnosu na AoMS.

\section{EPIDEMIOLOŠKE DETERMINANTE MULTIPLE SKLEROZE KOD DECE I ADOLESCENATA}

Pedijatrijska multipla skleroza spada u retke bolesti, sa početkom pre navršene 18 . godine kod 2 do $11 \%$ obolelih, a izuzetno retko se javlja pre 10. godine, u oko $0,3 \%$ (28). U tom kontekstu, poznavanje uzrasno - specifičnih stopa incidencije MS je važno u dijagnostičkom pristupu detetu sa akutnim neurološkim simptomima, povećavajući verovatnoću postavljanja dijagnoze, a samim tim i početak lečenja. Uzajamna interakcija genetičkih i sredinskih faktora određuje rizik za pojavu multiple skleroze.

Najviša incidencija bolesti je na uzrastu od 13. do 16 . godine (28). Registrovane stope incidencije MS kod dece $i$ adolescenata široko variraju između različitih zemalja. Do sada je najviša stopa incidencije MS kod dece mlađe od 18 godina registrovana na Sardiniji $(2,85 / 100.000$ osoba, godišnje) $(28,29)$, a najniža na Islandu $(0,45 / 100.000$ osoba, godišnje) (28). Prevalencija AoMS na Sardiniji je blizu 300/100.000, što predstavlja rezultat genetičkih i bioloških varijacija sardinijske populacije i njihovih interakcija sa sredinskim faktorima prisutnim u detinjstvu $(28,29)$. Imunogenetičke promene koje su se tom prilikom desile, učinile su ovu populaciju podložnijom za autoimunske bolesti.

Prema podacima Registra za MS Danske, prosečna godišnja stopa incidencije PedMS iznosila je 0,79/100.000 osoba godišnje, u periodu 1977-2015. godine, sa niskim vrednostima do 9. godine kod devojčica i 11. godine kod dečaka i odnosom polova 2,5:1 (30). U ovom Registru je zabeleženo samo 11 slučajeva PedMS sa početkom pre 11. godine (30). Uzrasno - specifične stope incidencije MS imale su očekivanu distribuciju.

Prema pojedinim autorima, zabeležen je porast stope hospitalizacija u Sjedinjenim Američkim Državama (SAD) sa 2,37 na 4,13/10.000 u pedijatrijskoj populaciji (31). Takođe je povećana svest o PedMS i povećan je broj specijalizovanih PedMS centara (31).

Kuvajt je blisko-istočna zemlja u kojoj MS nije tako česta bolest u poređenju sa drugim delovima sveta, međutim i ovde je registrovan porast incidencije od 0,3 na $2,1 / 100.000$ u pedijatrijskoj populaciji. Prevalencija je porasla sa 1,3 na $6,0 / 100.000$ (32), sa posledičnim po- 
većanjem svesnosti lekara i populacije, promenom socio-ekonomskog statusa i poboljšanjem pristupačnosti zdravstvenom sistemu.

Većina osoba sa početkom MS u pedijatrijskom uzrastu (90\%) ima relapsno-remitentnu PedMS, sekundarno-progresivna forma je retka, a primarno-progresivna PedMS izuzetno retka $(8,9)$.

Interakcije genetičkih i sredinskih faktora u etiologiji MS su veoma kompleksne i još uvek nisu u potpunosti razjašnjene. Populaciona studija slučajeva i kontrola sprovedena u Francuskoj, koja je uključivala decu sa MS uzrasta do 16 godina, pokazala je da su deca čiji su roditelji pušači imala dvostruko veći rizik od nastanka bolesti (33). U populacionoj studiji slučajeva i kontrola izvedenoj u Švedskoj, zaključeno je da je rizik za nastanak MS udružen sa pojedinim HLA genotipovima pod značajnim uticajem pušačkog statusa (34).

\section{IMUNSKA OSNOVA PEDIJATRIJSKE MULTIPLE} SKLEROZE

Iako se klinički tok PedMS razlikuje od bolesti koja počinje u adultnom dobu, smatra se da su osnovni imunopatogenetski mehanizmi isti. Ključni događaj je infiltracija imunskih ćelija u CNS koja započinje inflamatornu kaskadu i rezultira demijelinizacijom i neurodegeneracijom (12). Ipak, postoje imunološke osobenosti PedMS, koje je razlikuju u odnosu na AoMS.

Manja učestalost PedMS nije posledica nezrelosti imunskog sistema (IS) pošto se kritični događaji u razvoju IS kod ljudi odigravaju pre rođenja, pa se deca rađaju sposobna da odgovore na patogene i regulišu odgovore na sopstvene i neškodljive strane antigene. Ipak, razvoj IS je dinamičan proces koji se menja tokom života. Rani životni period karakteriše veći broj naivnih limfocita u odnosu na memorijske i relativno visok broj regulatornih T ćelija (Treg) (35). Međutim, kod dece obolele od MS broj naivnih T limfocita je niži, a broj memorijskih viši u odnosu na zdravu decu istog uzrasta i odgovara onom kod odraslih pacijenata, što ukazuje na raniju involuciju timusa. Kod obolele dece je smanjena aktivnost Treg, a povećana produkcija proinflamatornih citokina. Postoji značajna razlika u homeostazi B limfocita u krvi i likvoru obolelih od MS koja zavisi od uzrasta, sa dominacijom plazmablasta kod dece $(12,35)$.

Kod obolele dece, akutna oštećenja aksona u ranim aktivnim lezijama značajno su intenzivnija, a CNS lezije sadrže više makrofaga u poređenju sa odraslim bolesnicima $(12,35)$. Analiza proteoma cerebrospinalne tečnosti kod dece obolele od MS sugeriše da su primarni autoantigeni molekuli akso-glijalnog aparata, a ne antigeni kompaktnog mijelina (MBP, PLP, OSP). Anti-MOG antitela su retko prisutna u serumu dece obolele od MS i njihov nalaz na početku bolesti ukazuje na mogući razvoj drugih bolesti u okviru stečenog demijelinizacionog sindroma CNS (36).

Različiti imunopatološki i biološki mehanizmi, izraženije inflamatorne promene u CNS, restorativni kapacitet i plasticitet, uslovljavaju drugačije kliničko ispoljavanje sa ranijim dostizanjem onesposobljenosti i razlikama u odgovoru na primenjenu terapiju. Saznanja o imunološkim sličnostima i razlikama između PedMS i MS odraslih bitna su za izbor i primenu imunomodulatornih lekova kod dece.

\section{DiJAgnostičKi PRISTUP PEDIJATRIJSKOJ MULTIPLOJ SKLEROZI}

Nalazi na magnetnoj rezonanciji (MR) su od fundamentalnog značaja u postavljanju dijagnoze i u pogledu prognoze. Kriterijumi za postavljanje dijagnoze PedMS su modifikovani u odnosu na prethodne kriterijume, sa većim značajem opterećenosti lezijama koje su češće lokalizovane u moždanom stablu i cerebelumu. Demijelinizacione lezije pokazuju manju destruktivnost, izraženiju inflamatornu komponentu i veću sklonost oporavku tokom vremena.

Prema dosadašnjim kritrijumima za potvrđivanje dijagnoze PedMS, djagnostički algoritam se razlikovao u odnosu na onaj koji se primenjuje u adultnoj populaciji. Međutim, prema najnovijim dijagnostičkim kriterijuma za AoMS (37), preporučeno je da se kod dece starije od 11 godina u potpunosti mogu primeniti osnovni principi dijagnostičkog postupka kao i za AoMS, s obzirom da $80 \%$ PedMS ima istu kliničku prezentaciju kao kod odraslih, kao i da nalaz na MR mozga ne pokazuje supstancijalne razlike u odnosu na nalaz koji se vidi kod odraslih (37). Shodno tome, prema ovim kriterijumima, nephodno je da dijagnostički postupak obuhvata integraciju tipičnih kliničkih i parakliničkih pokazatelja koji na terenu tipične kliničke slike treba da potvrde diseminaciju u vremenu i prostoru, kao i da isključe druge bolesti CNS koje diferencijalno dijagnostički dolaze u obzir. U parakliničke pokazatelje spadaju MR mozga i kičmene moždine kao i pregled likvora (37). Najznačajnija paraklinička dijagnostička metoda je MR mozga i kičmene moždine.

Pomoću MR može se lako dokazati diseminacija u vremenu i prostoru u PedMS, a prema novim dijagnostičkim kriterijumima moguće je postaviti dijagnozu relapsno-remitentne MS nakon samo jednog, odnosno prvog ataka bolesti (klinički izolovani sindrom koji sugeriše demijelizaciju) (37). Da bi se potvrdila dijagnoza PedMS neophodno je i da se isključe sve druge bolesti koje diferencijalno dijagnostički mogu dati istu kliničku sliku.

Promene koje se javljaju u okviru AoMS i PedMS imaju karakterističan nalaz na MR mozga. Promene su u 
Tabela 1 - Algoritam za potvrđivanje dijagnoze relapsno-remitentne multiple skleroze

\begin{tabular}{|c|c|c|}
\hline & $\begin{array}{l}\text { Broj objektivnih lezija u } \\
\text { kliničkom nalazu }\end{array}$ & Neophodno za definitivnu dijagnozu \\
\hline$\geq 2$ klinička ataka & $\geq 2$ & Ništa $^{*}$ \\
\hline$\geq 2$ klinička ataka & $\begin{array}{l}1 \\
\text { (sigurni podaci o prethodnom } \\
\text { ataku koji potvrđuje zahvaćenost drugog } \\
\text { regiona }\end{array}$ & Ništa $^{*}$ \\
\hline$\geq 2$ klinička ataka & 1 & $\begin{array}{l}\text { Diseminacija u prostoru } \\
\text { 1. Novi klinički atak sa nove lokalizacije } \\
\text { ILI } \\
\text { 2. Dokaz diseminacije u prostoru na MR }\end{array}$ \\
\hline 1 klinički atak & $\geq 2$ & $\begin{array}{l}\text { Diseminacija u vremenu } \\
\text { 1. Novi klinički atak } \\
\text { ILI } \\
\text { 2. Dokazati diseminaciju na MR } \\
\text { ILI } \\
\text { 3. Oligoklonalne IgG trake u likvoru*** }\end{array}$ \\
\hline 1 klinički atak & 1 & $\begin{array}{l}\text { Diseminacija u prostoru } \\
\text { 1. Novi klinički atak sa nove lokalizacije } \\
\text { ILI } \\
\text { 2. MR diseminacija u prostoru } \\
\text { I } \\
\text { Diseminacija u vremenu } \\
\text { 1. Novi klinički atak } \\
\text { ILI } \\
\text { 2. Dokazati diseminaciju na MR } \\
\text { ILI } \\
\text { 3. Oligoklonalne IgG trake u likvoru** }\end{array}$ \\
\hline
\end{tabular}

${ }^{\star}$ Postoje dva jasno dokumentovana ataka bolesti sa dokazom o diseminaciji u prostoru u neurološkom nalazu: kod svih pacijenata je apsolutno neophodna MR mozga. MR kičmene moždine i pregled likvora su indikovani u nedostatku kliničkih i dokaza na MR mozga ili kod atipične kliničke slike. ${ }^{* *}$ Dokumentovana potvrda o ranijem događaju koji je zahvatio drugu lokalizaciju. ${ }^{* *}$ Za detekciju oligoklonalnih IgG traka u likvoru je neophodna metoda izoelektričnog fokusiranja likvora i seruma.

Modifikovano prema: Thompson A, et al. Lancet Neurol 2018. (37)

obliku multifokalnih zona povišenog intenziteta signala na T2W (T2-weighted), proton density (PD) i Fluid - attenuated inversion recovery (FLAIR) sekvencama. Karakteristična predilekciona mesta su: periventrikularna bela masa, korpus kalozum, duboka bela masa, jukstakortikalni regioni i infratentorijalni regioni mozga (cerebelum i moždano stablo), a takođe se promene mogu videti na kičmenoj moždini (KM) i optičkom živcu (38). Promene su najčešće iregularne ovoidne ili okrugle, relativno su dobro ograničene i imaju asimetrični raspored, dok veličina promena u mozgu može varirati od nekoliko milimetara (najmanje $3 \mathrm{~mm}$ ) do više od jednog centimetra u prečniku i često se prebojavaju kontrastom (39).
Dijagnostički značaj imaju samo promene ukoliko se na MR detektuje $\geq 1$ T2 lezije u dva od četiri navedena regiona: periventrikularno, infratentorijalno, kičmena moždina i kortikalno/jukstakortikalno. Ovakve promene predstavljaju diseminaciju u prostoru (37).

Da bi se potvrdila diseminacija u vremenu, neophodno je da se ispuni jedan od dva uslova: 1. istovremeno prisustvo promene koja se prebojava kontrastom i T2 promene koja se ne prebojava kontrastom u bilo kom momentu, kao i referentni snimak, ili 2. Nova T2 promena i/ili promena koja se prebojava kontrastom na novom snimku MR bez obzira kada je urađen referentni

Tabela 2 - Algoritam za potvrđivanje dijagnoze relapsno-remitentne multiple skleroze kod dece

1 Dva ili više ne-encefalopatskih događaja koji se javljaju u razmaku od najmanje 30 dana i koji zahvataju više od jednog regiona CNS.

2 Prvi neurološki događaj (bez encefalopatije) koji je tipičan za MS + nalaz na MR kojim se potvrđuje diseminaciju u vremenu i prostoru prema revidiranim McDonaldovim kriterijumima iz 2010. godine (12-18 godina starosti)

3 Prvi neurološki događaj (bez encefalopatije) koji je tipičan za MS + nalaz na MR gde su ispunjeni revidirani McDonaldovi kriterijumi iz 2010. godine kojim se potvrđuje diseminacija u prostoru. Za diseminaciju u vremenu je potrebno da se detektuje najmanje jedna nove lezije koja se prebojava ili se ne prebojava kontrastom na novom snimku koji je obavljen najmanje 30 dana u odnosu na prethodni

4

ADEM-like početak bolesti nakon kojeg se javlja nova neurološka epizoda sa ne-encefalopatskom kliničkom slikom nakon tri-četiri meseca od ADEM-like ataka, a MR pokazuje pojavu novih promena kojim se ispunjavaju McDonaldovi kriterijumi iz 2010. godine za diseminaciju u prostoru. 
snimak. Takođe diseminaciju u vremenu prema novim dijagnostičkim kriterijumima se potvrđuje i prisustvom oligoklonalnih traka u likvoru (37).

Kada su u pitanju deca mlađa od 11 godina, verovatnoća da će prvi neurološki događaj imati sliku akutnog diseminovanog encefalomijelitisa je velika, te je i postupak potvrđivanja dijagnoze PedMS kod ove populacije i dalje drugačiji (Krupp i sar., 2013).

Poslednjih godina, sve je više publikacija o kortikalnim lezijama na MR, kao i razvoju sekvenci koje mogu da detektuju plakove u korteksu. Aktuelna preporuka je da se koristi 3D DIR (Double Inverson Recovery) sekvenca, koja omogućava dobru vizuelizaciju sive mase uz istovremeno suprimiranje signala bele mase i likvora. Kortikalne lezije se na DIR sekvenci prikazuju kao hiperintenzne. Takođe se preporučuje da se promene moraju potvrditi na još jednoj sekvenci, T1-weighted MPRAGE (41).

Postoji svega nekoliko radova o kortikalnim promenama u PedMS. Prva studija koja je rađena na MR 1,5T (42) sugeriše da se kortikalni plakovi mogu detektovati kod 34\% bolesnika. U drugoj studiji na MR 3T (43), plakovi su detektovani u korteksu $79 \%$ bolesnika, dok je 100\% PedMS imalo ranu zahvaćenost korteksa, kao i dominatne lezije mešovitog tipa na MR 7T (44).

Mogućnost MR da pokaže diseminaciju u vremenu i prostoru omogućava rano postavljanje dijagnoze, što je od ključnog značaja za pravovremeno započinjanje imunomodulatorne terapije (IMT) i menjanje prirodnog toka bolesti.

\section{Terapija PedijatrijSKe MUltiple SKLEROZE}

Terapija PedMS podrazumeva lečenje egzacerbacija bolesti, primenu imunomodulatornih/imunosupresivnih lekova (IMT/IST), simptomatsku terapiju i neurorehabilitaciju. U terapiji egzacerbacija se intravenski primenjuju visoke doze kortikosteroida i plazmafereza, a po potrebi i imunoglobulini (45).

Lečenje egzacerbacija - relapsa bolesti podrazumeva upotrebu visokih doza kortikosteroida (metilprednizolon 20-30 mg/kg, maksimalno $1000 \mathrm{mg} /$ dan i.v.), jednom dnevno. Neželjeni efekti ove terapije kod dece uključuju poremećaje raspoloženja, eritem obraza, veći apetit i telesnu masu, akne, nesanicu, hipertenziju, aritmije, hiperglikemiju i ulceracije na želucu (neophodna je istovremena upotreba gastroprotektivnih lekova) (45, 46). Ako se nakon primenjene "pulsne" terapije kortikosteroidima pacijent nije u potpunosti oporavio, može se započeti sa per os primenom prednizona (Pronizon) $\mathrm{u}$ dozi od $1 \mathrm{mg} / \mathrm{kg}$ dnevno (maksimalna doza $60 \mathrm{mg} /$ dan) $(46,47)$. Druga terapijska linija za lečenje relapsa
PedMS, za pacijente kod kojih dolazi do brze progresije bolesti ili nepovoljnog odgovora na "pulsnu" terapiju, je primena plazmafereze (46). Ako posle terapije kortikosteroidima nema poboljšanja u kliničkoj slici, ili se kliniko stanje pacijenta pogoršava, kod dece sa PedMS može se započeti primena i.v. imunoglobulina u dozi od $0,4 \mathrm{~g} / \mathrm{kg} / \mathrm{dan}$, narednih 5 dana $(46,47)$. Za razliku od PedMS pacijenata, kod AoMS pacijenata se ne primenjuju i.v. imunoglobulini.

IMT/IST, lekovi koji menjaju prirodni tok bolesti, podeljeni su na lekove umerene efektivnosti (interferon beta-1a, interferon beta-1b, glatiramer acetat, dimetil fumarat, teriflunomid) i visoke efektivnosti (natalizumab, fingolimod, alemtuzumab, kladribin tablete, okrelizumab) koji se koriste u slučaju delimične ili potpune nedelotvornosti prve linije. U retkim slučajevima agresivne forme bolesti mogu se primeniti ciklofosfamid, i mitoksantron.

Među lekove umerene efektivnosti spadaju interferon beta-la (Rebif, Avonex), interferon beta-1b (Betaferon) i glataramer acetat (Copaxone). Rebif se daje s.c. 3 puta nedeljno u dozi od 22 do $44 \mathrm{mg}$, dok se Avonex ordinira i.m. jednom nedeljno u dozi od $30 \mathrm{mg}$. Interferon beta- 1 b se daje s.c. svakog drugog dana, a glatiramer acetat tri puta nedeljno s.c, u dozama od $250 \mathrm{mg}$, odnosno 40 mg (48). Ova klasa lekova može da dovede do smanjenja učestalosti relapsa i za 30\% (49). Ovi lekovi značajno smanjuju učestalost i težinu kliničkih relapsa, aktivnost oboljenja, što se vidi i na MR mozga, a dovode i do smanjenja stepena invaliditeta $(48,49)$. Rezultati primene interferona beta-1a kod mlađe dece (2-11 godina) su pokazali sličan sigurnosni profil (53).

Najčešći neželjeni efekti interferona koji je primenjivan kod dece su: simptomi slični gripu, reakcija kože na mestu injekcije (češće pri s.c. davanju nego kod i.m), umor, mijalgija, glavobolja, mučnina, poremećaj u funkciji štitaste žlezde, alergijske reakcije (osip, urtikarija, anafilaksa), anemija, limfopenija, neutropenija, epilepsija i epileptični napadi, autoimune bolesti, poremećaji hrskavice i kostiju i povišene vrednosti enzima jetre (46, 48). Kod pacijenata koji imaju gripu slične simptome primenjuju se paracetamol ili ibuprofen.

Glatiramer acetat može prouzrokovati prolaznu reakciju u vidu crvenila i osećaja toplote praćenu tahikardijom koja može da bude jako neprijatna za pacijente (50).

Fingolimod (Gilenia) tablete (0,5 mg ili 0,25 mg dnevno za pacijente sa telesnom masom od $\leq 40 \mathrm{~kg}$ ) se ordiniraju oralno, jednom dnevno, što značajno olakšava primenu kod PedMS pacijenata (51). Fingolimod je modulator receptora sfingozin-1-fosfata, čime sprečava migraciju limfocita iz limfnih žlezda, a posledično smanjuje broj limfocita u CNS $(51,52)$. Prema studijama PedMS pacijenti kod kojih je primenjen fingolimod imali su nižu 
stopu relapsa, a takođe i manju akumulaciju lezija na MR od PedMS pacijenata lečenih interferonom beta-1a (51). Kod PedMS pacijenata su prijavljeni i neželjeni efekti kao što su: infekcije, epileptični napadi i leukopenija (51), dok su u drugim studijama zabeleženi: abnormalni srčani ritam (posebno bradikardija) posle prve doze leka, povećanje nivoa hepatičnih enzima, maligna proliferacija tumora i PML (52).

Lečenje osiguranih lica obolelih odPedMS i AoMS u Srbiji može se sprovesti na teret sredstava zdravstvenog osiguranja i to do sada, primenom interferona beta i glatiramer acetata. Kriterijumi za započinjanje terapije su: samostalno pokretni bolesnici koji mogu da predju više od $300 \mathrm{~m}$ (EDSS $\leq 4.5)$, starosti iznad 2 godine (Rebif $44 \mathrm{mcg}$, sc. 3x nedeljno) ili iznad 12 godina (Betaferon $8 \mathrm{MIU}$, sc. na II dan, Avonex $6 \mathrm{MIU}$, im. 1x nedeljno, ili Copaxone $20 \mathrm{mg}$, sc. 1x dnevno). Takođe je neophodno da pacijenti imaju aktivnu, relapsno-remitentnu formu MS (najmanje dva relapsa u poslednje 2 godine, čija je dijagnoza postavljena prema Revidiranim McDonaldovim kriterijumima iz 2010. godine. Terapija se prekida u slučaju neefikasnosti kod osoba: kod kojih se egzacerbacije javljaju sa istom ili većom učestalošću u odnosu na period pre primene terapije (u prethodnoj godini ili prethodne 2 godine); kod kojih se stanje progresivno pogoršava i kod pacijenata sa teškim neželjenim efektima ili graviditetom.

Prevalencija i incidencija PedMS je u porastu na globalnom nivou (53). Rano započinjanje IMT/IST prevenira akumulaciju onesposobljenosti i smanjuje nagomilavanje oštećenja u CNS. Specifičnosti razvojnog doba uzrokuju značajne nepodudarnosti u efikasnosti, sigurnosnom profilu i terapijskom odgovoru.

\section{ZaKLJUČAK}

Posebnost PedMS čini veća učestalost egzacerbacija sa boljim oporavkom, česta kognitivna disfunkcija, sporija progresija bolesti, izraženije inflamatorne promene u CNS, multifokalni, početak sličan akutnom diseminovanom encefalomijelitisu i redak primarno progresivan tok bolesti. Različiti imunopatološki i biološki mehanizmi, restorativni kapacitet i plasticitet, uslovljavaju drugačije kliničko ispoljavanje sa ranijim dostizanjem onesposobljenosti u odnosu na pacijente kod kojih je bolest počela u odraslom dobu.

\section{Literatura}

1. Pena JA, Lotze TE. Pediatric multiple sclerosis: current concepts and consensus definitions. Autoimmune Dis. 2013;2013:673947.

2. Compston A. The 150th anniversary of the first depiction of the lesions of multiple sclerosis.J Neurol Neurosurg Psychiatry. 1988;51(10):1249-52.

3. Orrell RW. Multiple sclerosis: the history of a disease. J R Soc Med. 2005;98(6):289.

4. Ebers GC. Environmental factors and multiple sclerosis. Lancet Neurol. 2008;7(3):268-77.

5. Murray TJ. The history of multiple sclerosis: the changing frame of the disease over the centuries. J Neurol Sci. 2009;1(277 Suppl 1):S3-S8.

6. Chitnis T. Disease-modifying therapy of pediatric multiple sclerosis. Neurotherapeutics. 2013;10(1):89-96.

7. Patel Y, Bhise V, Krupp L. Pediatric multiple sclerosis. Ann Indian Acad Neurol. 2009;12(4):238-45.

8. Ghezzi A, Baroncini D, Zaffaroni M, Comi G. Pediatric versus adult MS : similar or different?. Multiple Sclerosis and Demyelinating Disorders.2017;2:5. doi:10.1186/s40893-017-0022-6.

9. Chitnis T. Paediatric MS is the same disease as adult MS: no. Mult Scler. 2013 Sep;19(10):1255-6. doi: 10.1177/1352458513488842.

10. Bernard CC, de Rosbo NK. Multiple sclerosis: an autoimmune disease of multifactorial etiology. Curr Opin Immunol. 1992;4(6):760-5.

11. Cree BA. Multiple sclerosis genetics. Handb Clin Neurol. 2014;122:193-209.

12. Hintzen R, Dale R, Neuteboom R, Mar S, Banwell B. Pediatric Acquired CNS Demyelinating Syndromes: Features Associated With Multiple Sclerosis. Neurology. 2016;87(9):S67-73.

13. Zhou Y, Zhu G, Charlesworth JC, Simpson S Jr, Rubicz R, Göring HH et al. ANZgene consortium. Genetic loci for Epstein-Barr virus nuclear antigen-1 are associated with risk of multiple sclerosis. Mult Scler. 2016;22(13):1655-64.

14. Faridar A, Eskandari G, Sahraian MA, Minagar A, Azimi A. Vitamin $\mathrm{D}$ and multiple sclerosis: a critical review and recommendations on treatment. Acta Neurol Belg. 2012;112(4):327-33.

15. Wingerchuk DM. Smoking: effects on multiple sclerosis susceptibility and disease progression. Ther Adv Neurol Disord. 2012;5(1):13-22.
16. Gianfrancesco M, Stridh P, Rhead B, Shao X, Xu E et al. Evidence for a causal relationship between low vitamin D, high BMI, and pediatric-onset MS. Neurology. 2017; 88(17):1623-9.

17. Waubant E, Mowry EM, Krupp L, et al. Common viruses associated with lower pediatric multiple sclerosis risk. Neurology. 2011;76(23):1989-95.

18. Pfeifenbring S, Bunyan RF, Metz I, Röver C, Huppke P, Gärtner J, Lucchinetti CF, Brück W. Extensive acute axonal damage in pediatric multiple sclerosis lesions. Ann Neurol. 2015 Apr;77(4):655-67. doi: 10.1002/ana.24364.

19. Wu GF, Alvarez E. The immunopathophysiology of multiple sclerosis. Neurol Clin. 2011;29(2):257-78.

20. Chitnis T, Pohl D. Pediatric demyelinating disorders: Global updates, controversies, and future directions. Neurology. 2016;87(9):S1-S3.

21. Banwell B, Ghezzi A, Bar-Or A, Mikaeloff Y, Tardieu M. Multiple sclerosis in children: clinical diagnosis, therapeutic strategies, and future directions. Lancet Neurol. 2007;6(10):887-902.

22. Yilmaz Ü, Anlar B, Gücüyener K; Turkish Pediatric Multiple Sclerosis Study Group. Characteristics of pediatric multiple sclerosis: The Turkish pediatric multiple sclerosis database. Eur J Paediatr Neurol. 2017 Nov;21(6):864-872. doi: 10.1016/j.ejpn.2017.06.004.

23. Calabrese M, Poretto V, Favaretto A, Alessio S, Bernardi V, Romualdi C, Rinaldi F, Perini P, Gallo P. Cortical lesion load associates with progression of disability in multiple sclerosis. Brain. 2012 Oct;135(Pt 10):2952-61. doi: 10.1093/brain/aws246.

24. Chiaravalloti ND, DeLuca J. Cognitive impairment in multiple sclerosis. Lancet Neurol. 2008 Dec;7(12):1139-51. doi: 10.1016/S14744422(08)70259-X.

25. Rocca MA, Amato MP, De Stefano N, Enzinger C, Geurts JJ, Penner IK, Rovira A, Sumowski JF, Valsasina P, Filippi M; MAGNIMS Study Group. Clinical and imagin assessment of cognitive dysfunction in multiple sclerosis. Lancet Neurol. 2015 Mar;14(3):302-17. doi: 10.1016/ S1474-4422(14)70250-9.

26. Baruch NF, O’Donnell EH, Glanz BI, Benedict RH, Musallam AJ, Healy BC, Rintell D, Chitnis T. Cognitive and patient-reported outcomes in adults with pediatric-onset multiple sclerosis. Mult Scler. 2016 Mar;22(3):354-61. doi: 10.1177/1352458515588781. 
27. Till C, Deotto A, Tipu V, Sled JG, Bethune A, Narayanan S, Arnold DL, Banwell BL. White matter integrity and math performance in pediatric multiple sclerosis: a diffusion tensor imaging study. Neuroreport. 2011 Dec 21;22(18):1005-9. doi: 10.1097/WNR.0b013e32834dc301.

28. Waldman A, Ness J, Pohl D, Simone IL, Anlar B, Amato MP, Ghezzi A. Pediatric multiple sclerosis. Neurology Aug 2016, 87 (9 Supplement 2) S74 - S81. doi:10.1212/WNL.0000000000003028

29. Dell'Avvento S, Sotgiu MA, Manca S, Sotgiu G, Sotgiu S. Epidemiology of multiple sclerosis in the pediatric population of Sardinia, Italy. Eur J Pediatr. 2016;175(1):19-29. doi: 10.1007/s00431-015-2588-3.

30. Boesen MS, Magyari M, Born AP, Thygesen LC. Pediatric acquired demyelinating syndromes: a nationwide validation study of the Danish National Patient Register. Clin Epidemiol. 2018;10:391-399. Published 2018 Apr 10. doi:10.2147/CLEP.S156997

31. Lavery AM, Banwell BL, Liu G, Waldman AT. Hospital admission rates for pediatric multiple sclerosis in the United States using the Pediatric Health Information System (PHIS). Mult Scler Relat Disord. 2016 Sep;9:5-10. doi: 10.1016/j.msard.2016.05.018.

32. Alroughani R, Akhtar S, Ahmed SF, Behbehani R, Al-Abkal J, AlHashel J. Incidence and prevalence of pediatric onset multiple sclerosis in Kuwait: 1994-2013. J Neurol Sci. 2015;353(1-2):107-10. doi: 10.1016/j.jns.2015.04.025.

33. Mikaeloff Y, Caridade G, Tardieu M, Suissa S; KIDSEP study group. Parental smoking at home and the risk of childhood-onset multiple sclerosis in children.Brain. 2007 Oct;130 (Pt 10): 2589-95.

34. Hedstrom AK, Sundqvist E,Baarnhielm M, Nordin N, Hillert J et. al. Smoking and two human leukocyte antigen genes interact to increase the risk for multiple sclerosis. Brain 2011: 134; 653-664. doi:10.1093/ brain/awq371.

35. Baecher-Allan C, Kaskow BJ, Weiner HL. Multiple Sclerosis: Mechanisms and Immunotherapy. Neuron. 2018 Feb 21;97(4):742-768. doi: 10.1016/j.neuron.2018.01.021.

36. Hemmer, B., Archelos, J.J. and Hartung, H.-P. (2002) New Concepts in the Immunopathogenesis of Multiple Sclerosis. Nature Reviews Neuroscience, 3, 291-301. http://dx.doi.org/10.1038/nrn784

37. Thompson AJ, Banwell BL, Barkhof F, Carroll WM, Coetzee T et al. Diagnosis of multiple sclerosis: 2017 revisions of the McDonald criteria. Lancet Neurol. 2018 Feb;17(2):162-173. doi: 10.1016/S14744422(17)30470-2.

38. Filippi M, Rocca MA, Arnold DL, Bakshi R, Barkhof F, DeStefano N, et al. EFNS guidelines on the use of neuroimaging in the management of multiple sclerosis. Eur J Neurol. 2006; 13: 313-325

39. Mesaroš Š, Drulović J. Dijagnoza multiple skleroze: Uloga magnetne resonance. U: Multipla skleroza (ur. Drulović i sar). Beograd: Medicinski fakultet, 2013: 49-73.

40. Krupp LB, Tardieu M, Amato MP, Banwell B, Chitnis T, Dale RC, Ghezzi A, Hintzen R, Kornberg A, Pohl D, Rostasy K, Tenembaum S. Wassmer E; International Pediatric Multiple Sclerosis Study Group.
International Pediatric Multiple Sclerosis Study Group criteria for pediatric multiple sclerosis and immune-mediated central nervous system demyelinating disorders: revisions to the 2007 definitions. Mult Scler. 2013;19(10):1261-1267. doi: 10.1177/1352458513484547.

41. Geurts JJ, Roosendaal SD, Calabrese M, Ciccarelli O, Agosta F, Chard DT, et al. MAGNIMS Study Group. Consensus recommendations for MS cortical lesion scoring using double inversion recovery MRI. Neurology, 2011; 76: 418-24.

42. Calabrese M, Seppi D, Romualdi C, Rinaldi F, Alessio S, Perini P, Gallo P. Gray matter pathology in MS: a 3-year longitudinal study in a pediatric population. AJNR Am J Neuroradiol. 2012 Sep;33(8):150711. doi: 10.3174/ajnr.A3011.

43. Maranzano J, Till C, Assemlal HE, Fonov V, Brown R. Canadian Pediatric Demyelinating Disease Network. Detection and clinical correlation of leukocortical lesions in pediatric-onset multiple sclerosis on multi-contrast MRI.Mult Scler. 2018 May 1:1352458518779952. doi: $10.1177 / 1352458518779952$.

44. Datta R, Sethi V, Ly S, et al. 7T MRI Visualization of Cortical Lesions in Adolescents and Young Adults with Pediatric-Onset Multiple Sclerosis. J Neuroimaging. 2017;27(5):447-452.

45. Patel Y, Bhise V, Krupp L. Pediatric multiple sclerosis. Ann Indian Acad Neurol. 2009;12(4):238-45.

46. Narula S. New Perspectives in Pediatric Neurology-Multiple Sclerosis.Curr Probl Pediatr Adolesc Health Care. 2016;46(2):62-9.

47. Yeshokumar AK, Narula S, Banwell B. Pediatric multiple sclerosis. Curr Opin Neurol. 2017 Jun;30(3):216-221. doi: 10.1097/ WCO.0000000000000452.

48. Ghezzi A. Therapeutic strategies in childhood multiple sclerosis. Ther Adv Neurol Disord. 2010;3(4):217-28.

49. Chitnis T. Disease-modifying therapy of pediatric multiple sclerosis. Neurotherapeutics. 2013;10(1):89-96.

50. Banwell B, Ghezzi A, Bar-Or A, Mikaeloff Y, Tardieu M. Multiple sclerosis in children: clinical diagnosis, therapeutic strategies, and future directions. Lancet Neurol. 2007;6(10):887-902.

51. Chitnis T, Arnold DL, Banwell B, Brück W, Ghezzi A, Giovannoni G, Greenberg B, Krupp L, Rostásy K, Tardieu M, Waubant E, Wolinsky JS, Bar-Or A, Stites T, Chen Y, Putzki N, Merschhemke M, Gärtner J; PARADIGMS Study Group. Trial of Fingolimod versus Interferon Beta-1a in Pediatric Multiple Sclerosis. N Engl J Med. 2018 Sep 13;379(11):1017-1027. doi: 10.1056/NEJMoa1800149.

52. Fragoso YD, Alves-Leon SV, Barreira AA, Callegaro D, Ferreira MLB, Finkelsztejn A, et al. Fingolimod prescribed for the treatment of multiple sclerosis in patients younger than age 18 years. Pediatr Neurol. 2015;53(2):166-8.

53. Alroughani R, Boyko A. Pediatric multiple sclerosis: a review. BMC Neurol. 2018;18(1):27. Published 2018 Mar 9. doi:10.1186/s12883-0181026-3 